\title{
Primary School Science Teachers' Creativity and Practice in Malaysia
}

\author{
Norazilawati Abdullah and Zainun Mustafa \\ National Child Development Research Centre \\ Faculty of Human Development, Universiti Pendidikan Sultan Idris, Malaysia \\ https://orcid.org/0000-0002-9755-4629 \\ https://orcid.org/0000-0002-0797-724X \\ Mahizer Hamzah and Amir Hasan Dawi \\ Faculty of Human Development, Universiti Pendidikan Sultan Idris, Malaysia \\ https://orcid.org/0000-0003-3108-3913 \\ https://orcid.org/0000-0003-0825-4307 \\ Mazlina Che Mustafa \\ National Child Development Research Centre \\ Faculty of Human Development, Universiti Pendidikan Sultan Idris, Malaysia \\ https://orcid.org/0000-0003-2746-2021 \\ Lilia Halim \\ Universiti Kebangsaan, Malaysia \\ https://orcid.org/0000-0002-0562-1696 \\ Salmiza Saleh \\ Universiti Sains, Malaysia \\ https://orcid.org/0000-0002-4854-2859 \\ Che Siti Hajar Aisyah Che Abdul Khalil \\ Faculty of Human Development, Universiti Pendidikan Sultan Idris, Malaysia \\ https://orcid.org/0000-0002-9173-6659
}

\begin{abstract}
Creative pedagogy has been explored extensively, and previous research suggests that there is a gap between the level and practice of creativity of science teachers, and that it varies by school location. The aim of this study was to determine the levels of creativity, and creativity practice of primary school science teachers, and differences in the levels of creativity and creativity practice of primary school science teachers based on school location. The Torrance Tests of Creative Thinking (TTCT) were used to acquire qualitative data from 20 participants, and a questionnaire of creativity practice in science teaching was used to collect
\end{abstract}


quantitative data from 409 participants. The qualitative data were analyzed according to the TTCT scoring technique and the quantitative data were analyzed descriptively using Statistical Package for the Social Sciences 26 . This study found that, that while overall teacher creativity was low, the teachers perceived that they employed highly creative practices. No difference was found in relation to environment, teaching aids, skills and science process skills of teachers in urban and rural areas. However, teachers in rural areas were more knowledgeable about creativity, while teachers in urban areas were better at practising it. This research provides baseline evidence on current practices in creative pedagogy of science teachers nationwide.

Keywords: creative pedagogy; creativity; Malaysia; primary school; science education; Torrance Tests of Creative Thinking (TTCT)

\section{Introduction}

Studies indicate that science subjects are deemed dull by students, which contributes to the low student involvement in science streams in Malaysia (Nachiappan et al., 2017). This phenomenon is more prevalent among rural students, and it creates a gap in achievement between students on the basis of school demographics (Fatin Aliah et al., 2014). Fatin Aliah et al. (2014) also discovered that, in addition to school location, teachers' comprehension of science content, and their pedagogical approach, contributed to students' interest in science. The Malaysian government has implemented a number of strategic advances, such as the National Education Policy, Malaysia Education Blueprint, and 3rd core of Eleventh Malaysia Plan, at the national level to encourage students to pursue science subjects. The intention is to make science education more vibrant and engaging for students, which supports the government's aspiration to make Malaysia a developed country that is advanced in science and technology - as outlined in the policy and clarified further in the 21st Century Learning agenda.

It is insufficient to emphasize creativity in the curriculum by concentrating exclusively on students. Teachers, as the key drivers of the quality of education, should value creativity and have the skills to create a learning atmosphere that encourages students to be creative in the classroom (Kandemir et al., 2019). Therefore, to boost student creativity, it would be beneficial to focus on improving teachers' skills. In science subjects, specifically, creative pedagogy is necessary to inspire students to experience and explore science beyond merely providing answers or writing notes, and to stimulate their motivation to participate actively in learning.

Despite creative pedagogy being widely recognized as being effective in fostering interest in science subjects - and this is explicitly stated in the national policy - the levels of creativity and practice of Malaysian teachers is still inconclusive (Chua et al., 2003; Hamsiah, 2004; Horng et al., 2005; Nachiappan et al., 2017; Said \& Alias, 2013). The researchers suggest that further research should be conducted to verify the creative pedagogy of science teachers in Malaysia. Therefore, the objectives of this study were to determine, 1) The level of creativity of primary 
school science teachers; 2) The level of creativity practices of primary school science teachers; and 3) The differences between the levels of creativity and creativity practices of primary school science teachers, based on school location.

This research will contribute to the shift in the 10th aspiration of the Malaysia Education Blueprint 2013-2025, which is to optimize students' potential by producing creative and innovative students, and to provide relevant information to succeed in the 3rd core of Eleventh Malaysia Plan, which relates to human capital development through championing development in STEM (science, technology, engineering, mathematics) fields.

\section{Literature Review}

\subsection{Creative Pedagogy}

Science is the systematic study of natural phenomena, which encourages students to participate in inquiry and critical and logical thinking, and to demonstrate scientific process skills when learning about the rich and fascinating natural world. With science being a subject that is taught formally through systematic education, the scientific enterprise is both exciting and challenging, therefore, it requires a creative approach. While creativity is mostly associated with literary streams, research on creative science teaching and learning is gaining attention in science education too (Craft et al., 2016).

In the Encyclopedia of Creativity, Invention, Innovation and Entrepreneurship, Aleinikov (2013) defines pedagogy in general as the "study of the process of teaching", and refers to creative pedagogy, specifically, as the "science and art of creative teaching". Aleinikov (2013) states, furthermore, that creative pedagogy is a branch of pedagogy that emphasizes the creation of new teaching strategies, or refashioning existing teaching strategies to ensure successful learning. Creative pedagogy, however, is interrelated with other terms used in literature, such as "teaching for creativity", "creative practice", "creativity in the classroom", "creative teaching", and "teaching creatively" (Cremin \& Chappell, 2019). From these terms, we can ascertain that creative pedagogy is not only a teaching strategy for imparting content knowledge to students; it also enables students to hold a positive attitude about the subject.

The concept of creative science teaching or creative pedagogy is embedded in several instances of unconventional teaching strategies, among which meaningful discovery (Khabibah et al., 2017; Wartono et al., 2017), student-based investigations (Allchin et al., 2014), inquiry in historical experiment exploration (Schvartzer et al., 2021), engagement in scientifically oriented inquiry (Cairns \& Areepattamannil, 2019; Wagh et al., 2017), prioritizing direct experience and personal reflection (Djonko-Moore et al., 2018; Horng et al., 2005), evidence-based explanations by a field expert (Castagneyrol et al., 2020; Kelemen-Finan et al., 2018), interdisciplinary STEM (Abdullah et al., 2018; Karampelas, 2019) and connecting explanations to scientific knowledge (Henriksen \& Mishra, 2015; Miller \& Krajcik, 2019). In addition to the listed strategies for teaching science content, skills and values, creative science learning is also infused in the way knowledge is transferred or communicated (Conradty et al., 2020). For instance, students use creative methods to present learning outcomes through creative 
movement (Kerby et al., 2010; Sagmeister et al., 2021), visual art (Liao, 2016), verbal literature (Januchowski-Hartley et al., 2018), and aesthetics (Maulidah et al., 2021). Another study, by Kant et al. (2017), reports that students exhibited learned science content creatively through cooking and quilt-making. The repertoire of content delivery and outcome formats in creative pedagogy can, furthermore, be enriched by using digital technology, including geographic information systems (GIS) and geovisualization tools (Delparte et al., 2016), augmented reality (Reeves et al., 2021), interactive software (Abdullah, 2017), gamification (Toth \& Kayler, 2015), animation and interactive environments (Johansson, 2001), mobile learning (Cotič et al., 2020), 3-D printing (Saorín et al., 2017), composing and remixing digital music (Engelman et al., 2017), to name a few. In all these strategies for science learning, creativity is the inclusive element, in both the knowledge-acquiring process and the knowledgedelivering/expressing process. In other words, creative pedagogy in science education encompasses the teaching of specific creative skills (teaching of creativity), the teaching of how scientists use creativity to develop scientific innovation (teaching about creativity), and the teaching of scientific concepts creatively (teaching through creativity).

Considering the importance of creativity in teaching, we must acknowledge that creative pedagogy itself is not developed in a vacuum. Studies suggest five important aspects related to understanding teacher creativity in teaching and learning in science classrooms, that is, teacher knowledge, the workplace environment, multifaceted use of teaching aids, teaching skills, and a focus on science process skills (i.e, Hamdallah et al., 2014; Henriksen \& Mishra, 2015; Horng et al., 2005; Maulidah et al., 2021). Cremin and Chappell (2019) suggest the that teachers have to understand and broaden their pool of pedagogical strategies in order to foster learners' creativity .

\subsection{Torrance's Creativity Theory}

The Torrance Test of Creative Thinking (TTCT) was introduced in the 1960s (Kim, 2006). The task-based test, which is still being used today, has been amended several times, translated into several languages, and adapted to various situations, and possesses good reliability and good predictive reliability. Initially, the test was scored on four scales or criterion-referenced scores: fluency, flexibility, originality and elaboration. The scales were later updated with the addition of "resistance to premature closure' and "abstractness of titles', and the omission of "flexibility". The test has been revised from time to time, and varied from the basic five scales to 13 scales, depending on the context of a study. The tasks can be divided into three types: verbal tasks using verbal stimuli, verbal tasks using non-verbal stimuli, and non-verbal tasks.

In this study, only nonverbal tasks or figural tasks were employed. This test was first used by researchers to measure the creativity of Malaysian students. Some local studies that utilized TTCT as the instrument were that of Chua et al. (2003), Hamsiah (2004) and Rafedah (2009). While the TTCT has been tested in various contexts in Malaysia for nearly 30 years, there is a need for new research on new population groups, as demographics are changing and earlier results do not represent the current samples (Bart et al., 2017). For this reason, and because of its 
high reliability value, widespread use, and good predictive reliability, the researchers decided to use TTCT in this study (Kim, 2006).

The current study sought to answer the following questions:

1. What are the levels of creativity and creativity practice of primary school science teachers?

2. What are the differences in the levels of creativity practice of primary school science teachers at different school locations?

\section{Methodology}

Teacher creativity was gauged using a mixed-method approach. Task-based TTCT was employed to acquire the qualitative data, while a questionnaire to measure creativity practice in science teaching was administered to gather quantitative data.

\subsection{Questionnaire}

The language of the questionnaire was Bahasa Melayu (Shazana, 2016) and consisted of 18 items representing six constructs (see Appendix A). The questionnaire was piloted and the reliability of the questionnaire was found to be 0.95. Normality of the data was assessed, and it was found that data were normally distributed, as skewness (0.388) and kurtosis $(-0.820)$ individually were within \pm 1 . Critical ratio ( $Z$ value) of the skewness $(0.688)$ and kurtosis $(-0.730)$ were within \pm 1.95 . The self-administered questionnaire consists of six constructs, namely knowledge, environment, teaching aids, skills, science process skills and attitudes. The sampling size was 409 primary school science teachers throughout the country, who were selected by purposive sampling.

\subsection{Torrance Creative Thinking Test}

While the questionnaire had to be completed by the respondents, the TTCT involved an interview session. Two types of tasks were chosen for this study three drawing tasks and three completing-picture tasks. Each task had to be completed in 10 minutes. Twenty teachers were chosen at random from the same sampling pool to participate in the TTCT. The requirements for each task were as follows: 1) The picture construction task required the participant to propose something from an indefinite purpose and to elaborate on it, so that a clear purpose emerged; 2) The picture-completion task required the participant to structure, integrate, and present an object, scene or situation; and 3) The repeated lines task required the participant to return to the same stimulus continuously and perceive it differently each time, by disrupting the structure to create something new. The tasks are summarized in Table 1. 
Table 1. The details of tasks, activities and criteria

\begin{tabular}{|c|c|c|}
\hline Task & Activity & Criteria \\
\hline $\begin{array}{l}\text { Picture } \\
\text { construction }\end{array}$ & $\begin{array}{l}\text { Participants were asked to draw a figure using a } \\
\text { given curved shape as the integral part of the } \\
\text { figures. } \\
\text { Participants were asked to tell an interesting and } \\
\text { exciting story by adding new ideas to the first } \\
\text { thought. } \\
\text { Participants were asked to give a creative and } \\
\text { unusual title to the figures. }\end{array}$ & $\begin{array}{l}\text { Originality } \\
\text { Elaboration } \\
\text { Abstractness of } \\
\text { title }\end{array}$ \\
\hline $\begin{array}{l}\text { Picture } \\
\text { completion }\end{array}$ & $\begin{array}{l}\text { Participants were asked to complete } 10 \\
\text { incomplete figures by adding lines to the } \\
\text { original picture to produce some interesting } \\
\text { figures and objects. } \\
\text { Participants were asked to give a creative and } \\
\text { unusual title to the figures. } \\
\text { The number of completed figures were } \\
\text { examined. }\end{array}$ & $\begin{array}{l}\text { Originality } \\
\text { Fluency } \\
\text { Elaboration } \\
\text { Resistance to } \\
\text { premature } \\
\text { closure } \\
\text { Abstractness of } \\
\text { titles }\end{array}$ \\
\hline Repeated lines & $\begin{array}{l}\text { Participants are given } 30 \text { pairs of straight lines } \\
\text { and they are asked to draw a picture with pairs } \\
\text { of straight lines } \\
\text { The number of completed figures and presence } \\
\text { of unusual figures were identified. } \\
\text { The participants were invited to express their } \\
\text { ideas to fully explain an interesting story }\end{array}$ & $\begin{array}{l}\text { Originality } \\
\text { Fluency } \\
\text { Elaboration }\end{array}$ \\
\hline
\end{tabular}

\section{Findings}

The 409 responses given on the questionnaire were analyzed using Statistical Package for the Social Sciences 26. In turn, the information gathered from the 20 participants on the task-based test was analyzed according with the TTCT scoring technique.

\subsection{The creativity level of primary school science teachers}

Table 2: The teachers' creativity level

\begin{tabular}{lcc}
\hline \multicolumn{1}{c}{ Level of creativity } & Number of teachers & Percentage \\
\hline Low & 13 & $65 \%$ \\
Moderate & 5 & $25 \%$ \\
High & 2 & $10 \%$ \\
\hline
\end{tabular}

According to Table 2, most of the participants showed a low level of creativity. Most participants (13 participants, or 65\%) had a low level of creativity. Participants with a moderate creativity level accounted for $25 \%$ of the total. Only $10 \%$ of the participants showed a high level of creativity. 


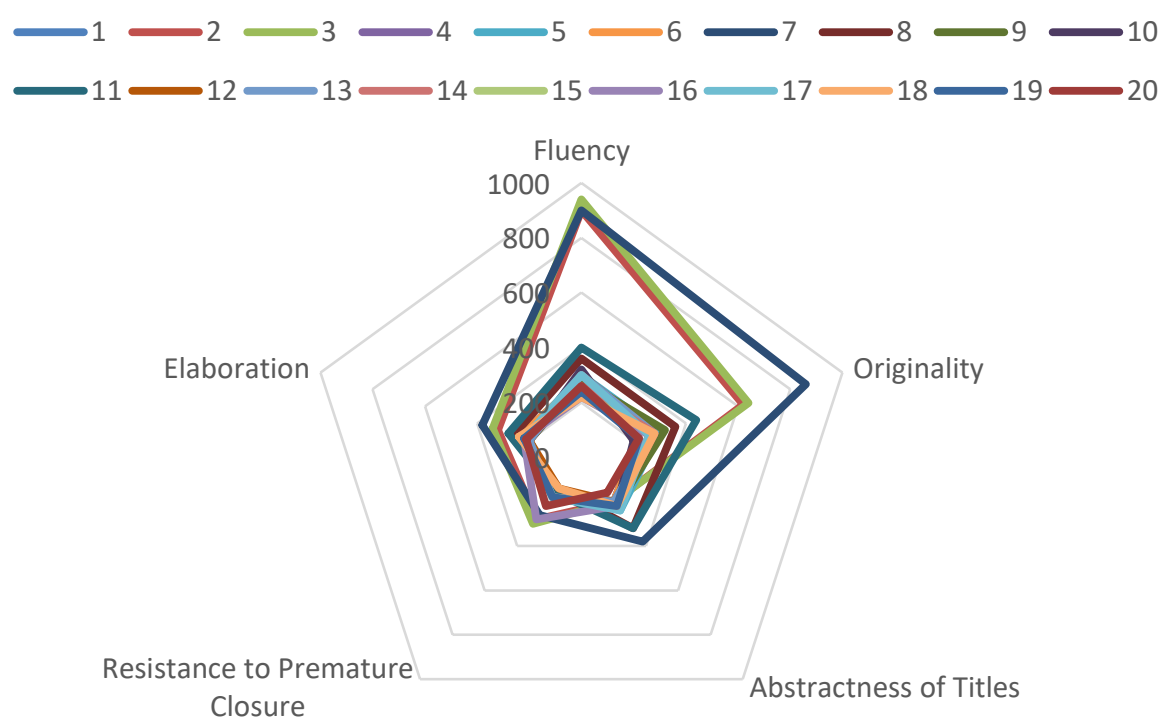

Figure 1: The spider plot of criteria of creativity

As evidenced by the spider plot in Figure 1, the teachers' creativity diverged towards fluency and originality. The higher levels of fluency and originality, over other criteria, reveal that the teachers had a higher likelihood of generating a great quantity and high quality of interpretable, meaningful, and relevant ideas in response to the stimulus. In contrast, reponses on the criteria of elaboration, resistance to premature closure and abstractness of titles converged towards the plot axis. The patterns in the plot indicate that the participants' ability to provide detail in their feedback, and to view the depth and richness of the figure, was somewhat restricted. The participants also appeared to be rushing to complete the task, which might hinder them from generating more ideas from the given stimulus. The overall pattern of the plot reveals that there are no outliers in any measured criteria, thereby indicating that all the teachers who participated in this study had a uniform level and type of creativity throughout all measured criteria. Since the participants were pooled from national school teachers who worked in the national education system and who had been trained in local teaching institutions, it is not surprising that they represented a fairly homogeneous sociocultural context and had undergone similar professional training.

\subsection{Level of creativity practice of primary school science teachers}

Table 3 shows that the primary school science teachers reported that they possessed high knowledge, environment, teaching aids, skills, science process skills and attitudes of all elements of creative practice. The mean scores for the teachers' knowledge, environment, teaching aids, skills, science process skills and attitudes components were $4.39,4.46,4.60,4.33,4.30$ and 4.37 respectively. The lowest mean was for science process skills of creative practice, namely 4.3 , while the highest score was for teaching aids, at 4.60. 
Table 3: The mean of overall level of creativity practice of teachers

\begin{tabular}{lccc}
\hline $\begin{array}{l}\text { Elements of creative } \\
\text { practice }\end{array}$ & Mean & Standard deviation & $\begin{array}{c}\text { Level of creativity } \\
\text { practice }\end{array}$ \\
\hline Knowledge & 4.39 & 0.504 & High \\
Environment & 4.46 & 0.514 & High \\
Teaching aids & 4.60 & 0.492 & High \\
Skills & 4.33 & 0.532 & High \\
Science process skills & 4.30 & 0.526 & High \\
Attitudes & 4.37 & 0.473 & High \\
\hline
\end{tabular}

\subsection{Comparing the elements of creativity practice of primary school science teachers according to school location}

Even though the overall level of creativity practice was high (Table 3), the elements of creative practice differed for different teaching locations. In other words, teachers who were located at schools in urban areas had a slightly different perception of creative teaching practices than those who worked at schools in rural areas.

Table 4: Knowledge of creative practice of teachers in urban and rural areas

\begin{tabular}{lllccccc}
\hline $\begin{array}{l}\text { Creative } \\
\text { practice } \\
\text { elements }\end{array}$ & $\begin{array}{l}\text { School } \\
\text { location }\end{array}$ & $\mathrm{N}$ & Mean & $\mathrm{sd}$ & $\mathrm{t}$ & $\mathrm{df}$ & $\mathrm{p}$ \\
\hline \multirow{2}{*}{ Knowledge } & Urban & 251 & 4.35 & 0.508 & -2.277 & 407 & 0.023 \\
& Rural & 158 & 4.46 & 0.491 & & & \\
\hline
\end{tabular}

Note: sd: standard deviation, df: degree of freedom, confidence level, $\mathrm{p}=0.05$

Table 4 shows the means for knowledge of creative practice of primary school science teachers located in urban areas $(\mathrm{M}=4.35, \mathrm{SP}=0.508)$ and rural areas $(\mathrm{M}=4.46, \mathrm{SP}=0.491)$. The t-test analysis shows that there was a significant difference, with $p=0.023$, which is $p<0.05$ with a value of $t(407)=-2.277$. Therefore, there is a significant mean difference in relation to knowledge of creative practice of primary school science teachers according to location of school - either in urban or rural areas.

Table 5: The environment of creative practice of teachers in urban and rural areas

\begin{tabular}{llccccccc}
\hline $\begin{array}{l}\text { Creative practice } \\
\text { elements }\end{array}$ & $\begin{array}{l}\text { School } \\
\text { location }\end{array}$ & $\mathrm{N}$ & Min & $\mathrm{sd}$ & $\mathrm{t}$ & $\mathrm{df}$ & $\mathrm{p}$ \\
\hline Environment & Urban & 251 & 4.47 & 0.515 & 0.855 & 407 & 0.393 \\
& Rural & 158 & 4.43 & 0.514 & & & \\
\hline
\end{tabular}

Note: sd: standard deviation, df: degree of freedom, confidence level, $\mathrm{p}=0.05$

Table 5 shows the mean environment of creative practice for primary school teachers in urban areas $(\mathrm{M}=4.47, \mathrm{SP}=0.515)$ and rural areas $(\mathrm{M}=4.43, \mathrm{SP}=0.514)$. The $t$-test analysis shows that there was no significant difference, with $\mathrm{p}=0.393$ $(p>0.05)$, and a value of $t(407)=0.855$. Therefore, there is no significant mean difference for the environment of creative practice according to the location of schools - whether in urban or rural areas. 
Table 6: Teaching aids supporting creative practice of the teachers in urban and rural areas

\begin{tabular}{llcccccc}
\hline $\begin{array}{l}\text { Creative practice } \\
\text { elements }\end{array}$ & $\begin{array}{l}\text { School } \\
\text { location }\end{array}$ & $\mathrm{N}$ & $\mathrm{Min}$ & $\mathrm{dd}$ & $\mathrm{t}$ & $\mathrm{df}$ & $\mathrm{p}$ \\
\hline Teaching Aids & Urban & 251 & 4.61 & 0.477 & 0.400 & 407 & 0.689 \\
& Rural & 158 & 4.59 & 0.517 & & & \\
\hline
\end{tabular}

Note: sd: standard deviation, df: degree of freedom, confidence level, $\mathrm{p}=0.05$

Table 6 shows the mean for the element of teaching aids in urban areas $(M=4.61$, $\mathrm{SP}=0.477)$ and rural areas $(\mathrm{M}=4.59, \mathrm{SP}=0.517)$. The $\mathrm{t}$-test analysis shows that there is no significant difference, where $p=0.689(p>0.05)$ with a value of $t(407)=0.400$. Therefore, there is no significant mean difference for teaching aids, which supports creative practice according to whether the school was located in an urban or rural area.

Table 7: Teachers' skill in employing creative practice in urban and rural areas

\begin{tabular}{llcccccc}
\hline $\begin{array}{l}\text { Creative practice } \\
\text { elements }\end{array}$ & $\begin{array}{l}\text { School } \\
\text { location }\end{array}$ & $\mathrm{N}$ & $\mathrm{Min}$ & $\mathrm{Sp}$ & $\mathrm{t}$ & $\mathrm{df}$ & $\mathrm{p}$ \\
\hline Skills & Urban & 251 & 4.34 & 0.546 & 0.756 & 407 & 0.443 \\
& Rural & 158 & 4.30 & 0.510 & & & \\
\hline
\end{tabular}

Note: sd: standard deviation, df: degree of freedom, confidence level, $\mathrm{p}=0.05$

Table 7 shows the mean for the teachers' skill in employing creative practice in urban areas $(\mathrm{M}=4.34, \mathrm{SP}=0.546)$ and rural areas $(\mathrm{M}=4.30, \mathrm{SP}=0.510)$. The t-test analysis shows that there is no significant difference: $p=0.443(p>0.05)$ with a value of $t(407)=0.756$ Therefore, there is no significant mean difference for the teachers' skill in employing creative practice according to school location, that is, whether they were teaching in urban or rural areas.

Table 8: Science process skills for employing creative practice in urban and rural areas

\begin{tabular}{llcccccc}
\hline $\begin{array}{l}\text { Creative practice } \\
\text { elements }\end{array}$ & $\begin{array}{l}\text { School } \\
\text { location }\end{array}$ & $\mathbf{N}$ & $\mathbf{m i n}$ & $\mathbf{s d}$ & $\mathbf{t}$ & $\mathbf{d f}$ & $\mathbf{p}$ \\
\hline \multirow{2}{*}{ Science Process Skills } & Urban & 251 & 4.30 & 0.545 & 0.400 & 407 & 0.968 \\
& Rural & 158 & 4.30 & 0.497 & & & \\
\hline
\end{tabular}

Note: sd: standard deviation, df: degree of freedom, confidence level, $\mathrm{p}=0.05$

Table 8 shows the mean for science process skills for employing creative practice by teachers in urban areas $(\mathrm{M}=4.30, \mathrm{SP}=0.545)$ and rural areas $(\mathrm{M}=4.30, \mathrm{SP}=0.497)$. The t-test analysis shows that there is no significant difference, with $\mathrm{p}=0.968(\mathrm{p}>$ 0.05 ), with a value of $\mathrm{t}(407)=0.400$. Therefore, there is no significant mean difference for the science process skills element according to the location of the school.

Table 9: Teachers' attitudes towards creative practice in urban and rural areas

\begin{tabular}{llcccccc}
\hline $\begin{array}{l}\text { Creative practice } \\
\text { elements }\end{array}$ & $\begin{array}{l}\text { School } \\
\text { location }\end{array}$ & $\mathbf{N}$ & Min & sd & $\mathbf{t}$ & $\mathbf{d f}$ & $\mathbf{p}$ \\
\hline \multirow{2}{*}{ Attitudes } & Urban & 251 & 4.40 & 0.462 & 1.873 & 407 & 0.062 \\
& Rural & 158 & 4.32 & 0.485 & & & \\
\hline
\end{tabular}

Note: sd: standard deviation, df: degree of freedom, confidence level, $\mathrm{p}=0.05$ 
Table 9 shows the mean of attitudes of the primary school science teachers towards creative practice according to school location in urban areas $(\mathrm{M}=4.40$, $\mathrm{SP}=0.462)$ and rural area $(\mathrm{M}=4.32, \mathrm{SP}=0.485)$. The $\mathrm{t}$-test analysis shows that there is a significant mean difference, that is, $p=0.062$, which is $p<0.05$ with a value of $t$ $(407)=1.873$. Therefore, there is a significant mean difference for the attitudes of primary school science teachers according to the location of their schools, namely, whether in urban or rural areas.

\section{Discussion}

The pattern of the findings could be explained by the design of the TTCT and the operational definition of "fluency" and "originality". Both criteria are tested in similar fashion to school-type tasks, e.g., a pen-and-pencil activity, which demands expressive writing (Humble et al., 2018) and which potentially requires the teacher to have this skill. The findings of this study confirmed previous research, which found that fluency and originality are interconnected (Kim, 2006), and sometimes referred to as one attribute (see Lillo \& Úbeda, 2017).

Meanwhile, the lower scores on abstractness of titles indicate that teachers had much more concrete and objective ideas about demonstrating their thoughts during task completion. This finding could reflect the strategy of teaching pedagogy taking place in the classroom. The science learning curriculum in Malaysia, which is domain-specific and goal-centric in approach, is geared to measuring the extent to which students master the content and concepts of lessons. Therefore, science education is meant to achieve the pre-planned learning objectives by using the exact terms, the right concept, and procedural lab practices. In other words, the teaching and learning of science are meant to be focused on facts, and should be free of bias or personal views. Even though Lam et al. (2010) found that achievement in science subjects was mildly associated with creativity, Chan (2011) claims that mathematics and natural sciences could promote creativity in children. Therefore, we emphasize that science teachers' lower scores in elaboration criteria are unlikely to be due to the nature of the subject, though it could signify the need for a creative pedagogical approach, in accordance with the nature of the science lesson itself.

The teachers sampled in this study taught primary school children at Piaget's concrete operational stage. We suggest that teaching children in the primary school stage (7-12 years) requires a more concrete learning strategy for addressing the development of cognitive ability. As the Malaysian curriculum is based on scaffolded learning, the teaching and learning in the primary school years are at basic and introductory levels, and the same lesson will be revisited in years ahead with much more abstractness and detail, as the children develop cognitive maturity. We propose that "concrete" should be an ally to creativity, at least in terms of science education in the primary school years. Several studies suggest that "concrete" creative pedagogy could promote interest in and understanding of primary school children in science subjects. Transforming abstract concepts into concrete representation ( $\mathrm{Lin} \& \mathrm{Liu}, 2016$ ), such as building a model of a microorganism (Hedegaard, 2020), using physical props and images (Astrachan, 1998), analogical reasoning with visual clues (Cubukcu \& Cetintahra, 2010), or exploring a wide range of students' answers (Purba, 2017), have been proven to 
support children at the level of cognitive development in science lessons. Therefore, the Torrance perception of abstractness should consider children's cognition as well.

The low scores in resistance to premature closure indicate that the teachers seemed to complete the given task using the quickest route. As professional adults who are required to handle a relatively large number of students at one time, teachers have probably developed the skills required to be adept at completing a planned lesson in the designated teaching period. In turn, the structure of examinations, which requires questions to be answered within an allocated period, might also influence teachers who have trained students to do this. Even though the low score on premature closure is associated with negative attributes in the creativity perspective, these same criteria could be valued as efficient time management features of the Malaysian teacher. The role of the teacher, as the professional adult, that is related to maintaining an orderly or structured learning environment, could contribute to low creativity. To achieve a degree of subjectivity and intangible structure in science lessons, teachers should open their minds to trial-and-error situations, provide ample time to complete lessons, lower the teacher-student ratio, exercise flexibility in the curriculum, and be free of objective testing. Professional development programs should train teachers in creative pedagogy (Hosseini \& Watt, 2010), and teachers should spend more time writing teaching plans, even though they have been certified as primary school teachers.

\section{Conclusion}

The results show that, while the teachers reported that their practices were highly creative, they actually demonstrated low creativity. In terms of creative practice, there was no difference between the teachers in urban and rural areas, except in relation to knowledge and attitudes. Teachers in rural areas had more knowledge of creativity, while teachers in urban areas were better at practicing creativity. The main concern arising from the finding relates to the discrepancy between what the teachers perceived to be taking place during their lessons, and what really takes place during lessons. Teachers believed that they employed highly creative practices that inculcated scientific creativity in students during lessons. However, teachers' levels of creativity were lower than what they believed it to be. In other words, the teachers believed that they knew about creativity, had the required skills and science process skills to instill creative thinking in students, and that the professional environment and teaching aids were sufficient for conducting creative pedagogy.

In reality, the level of teachers' creativity, as measured in this study, did not correspond with this perception. Teachers seemed to have limited creativity, and it was skewed to originality and fluency. In this study, we also found that creative pedagogy in primary school science education should consider the cognitive ability of students and the nature of science subjects. As science subjects focus on objectivity, uniform patterns and true scientific phenomena, creative pedagogy should focus on challenging students to be creative scientists, by applying various teaching and learning strategies. Therefore, the general idea of what is meant by creativity in science education needs to be refined further. To conclude, we 
acknowledge that creativity is an essential, innate aspect of teaching and learning, which contributes to human progress and scientific endeavors; however, we must consider how creativity is regulated - in this case, creative pedagogy in science education.

\section{Limitations and recommendations}

The gap that remains to be investigated after this study relates to understanding the curriculum content, which could benefit from much creative pedagogy through curriculum mapping and professional development feedback. Another important aspect that could be looked into is the need to balance out the concept of creative pedagogy in the schooling ecosystem in role players other than teachers, such as laboratory assistants, administrators, students and parents.

\section{Acknowledgements}

The authors extend their gratitude to the Ministry of Higher Education and the Research Management and Innovation Centre (RMIC), Sultan Idris Education University (UPSI) for the Fundamental Research Grants (code: 2019-0032-107-02 (FRGS/1/2018/SS109/UPSI/02/28)), which helped to fund the research.

\section{References}

Abdullah, N. (2017). Development of interactive software for implementing the science process skills in science primary school. International Journal of Academic Research in Business and Social Sciences, 7(6). https://doi.org/10.6007/IJARBSS/v7-i6/3033

Abdullah, N., Adnan, M., Ibharim, L. F., Hoe, T. W., Janan, D., Abdullah, J. M., Idris, N., \& Wahab, A. S. A. (2018). Development a year one stem comic for science and mathematics subjects. Jurnal Pendidikan Sains \& Matematik Malaysia, 8(2), 11-20.

Aleinikov, A. G. (2013). Creative pedagogy. In E. G. Carayannis (Ed.), Encyclopedia of creativity, invention, innovation and entrepreneurship (pp. 326-339). Springer New York. https://doi.org/10.1007/978-1-4614-3858-8_13

Allchin, D,. Møller Andersen, H., \& Nielsen, K. (2014). Complementary approaches to teaching nature of science: Integrating student inquiry, historical cases, and contemporary cases in classroom practice. Science Education, 98(3), 461-486. https://doi.org/10.1002/sce.21111

Astrachan, O. (1998). Concrete teaching: Hooks and props as instructional technology. ACM SIGCSE Bulletin, 30(3), 21-24. https:// doi.org/10.1145/290320.283003

Bart, W. M., Hokanson, B., \& Can, I. (2017). An investigation of the factor structure of the Torrance Tests of Creative Thinking. Educational Sciences: Theory \& Practice, 17(2). https:// doi.org/10.12738/estp.2017.2.0051

Cairns, D., \& Areepattamannil, S. (2019). Exploring the relations of inquiry-based teaching to science achievement and dispositions in 54 countries. Research in Science Education, 49(1), 1-23. https://doi.org/10.1007/s11165-017-9639-x

Castagneyrol, B., Valdés-Correcher, E., Bourdin, A., Barbaro, L., Bouriaud, O., Branco, M., Centenaro, G., Csóka, G., Duduman, M.-L., Dulaurent, A.-M., Eötvös, C. B., Faticov, M., Ferrante, M., Fürjes-Mikó, Á., Galmán, A., Gossner, M. M., Harvey, D., Howe, A. G., Kaennel-Dobbertin, M., ... Tack, A. J. M. (2020). Can school children support ecological research? Lessons from the Oak Bodyguard Citizen Science Project. Citizen Science: Theory and Practice, 5(1), 10. https://doi.org/10.5334/cstp.267

Chan, D. W. (2011). East vs. West. In M. Runco, \& S. Pritzker (Eds.), Encyclopedia of creativity (2 ${ }^{\text {nd }}$ ed., pp. 415-421). Elsevier. https://doi.org/10.1016/B978-0-12- 
375038-9.00082-0

Chua, Y. P., Sharifah. M. N., Naim. M., \& Wan Zah, W. A. (2003). Kreativiti guru pendidikan seni [Creativity of art education teachers]. Ertanika Journal Social $\mathcal{E}$ Humanistic, 11(1), 11-17.

Conradty, C., Lazoudis, A., \& Sotiriou, S. (2020). Stories of tomorrow. Students' visions on the future of space exploration. STORIES Deliverable D7.9: Digital Library. Final Conferences Proceedings. STORIES Consortium. https://ec.europa.eu/research/participants/documents/downloadPublic?docu mentIds $=080166 \mathrm{e} 5 \mathrm{c} 5594643$ \&appId=PPGMS on $17^{\text {th }}$ August 2021

Cotič, N., Plazar, J., Starčič, A. I., \& Zuljan, D. (2020). The effect of outdoor lessons in natural sciences on students' knowledge, through tablets and experiential learning. Journal of Baltic Science Education, 19(5), 747-763. https://doi.org/10.33225/jbse/20.19.747

Craft, A., Ben Horin, O., Sotiriou, M., Stergiopoulos, P., Sotiriou, S., Hennessy, S., Chappell, K., Slade, C., Greenwood, M., Black, A., Dobrivoje, E. L., Timotijević, Đ., Drecun, A., Brajović, A., Belmontecinzia, C., \& Conforto, G. (2016). CREAT-IT: Implementing creative strategies into science teaching. In M. Riopel, Z. Smyrnaiou (Eds.), New developments in science and technology education. Innovations in Science Education and Technology, Vol 23. (pp. 163-179). Springer. https://doi.org/10.1007/978-3-319-22933-1_15

Cremin, T., \& Chappell, K. (2019). Creative pedagogies: a systematic review. Research Papers in Education, 36(3), 1-33. https:/ / doi.org/10.1080/02671522.2019.1677757

Cubukcu, E., \& Cetintahra, G. E. (2010). Does analogical reasoning with visual clues affect novice and experienced design students' creativity? Creativity Research Journal, 22(3), 337-344. https:// doi.org/10.1080/10400419.2010.504656

Delparte, D. M., Richardson, R. T., Eitel, K. B., Jr., S. M., \& Cohn, T. (2016). Promoting geoscience STEM interest in Native American students: GIS, geovisualization, and reconceptualizing spatial thinking skills. International Journal of Learning, Teaching and Educational Research, 15(5), 1-15.

Djonko-Moore, C. M., Leonard, J., Holifield, Q., Bailey, E. B., \& Almughyirah, S. M. (2018). Using culturally relevant experiential education to enhance urban children's knowledge and engagement in science. Journal of Experiential Education, 41(2), 137153. https://doi.org/10.1177/1053825917742164

Engelman, S., Magerko, B., McKlin, T., Miller, M., Edwards, D., \& Freeman, J. (2017). Creativity in authentic STEAM education with EarSketch. Proceedings of the 2017 ACM SIGCSE Technical Symposium on Computer Science Education, 183-188. https://doi.org/10.1145/3017680.3017763

Fatin Aliah, P., Mohd Salleh, A., Mohammad Bilal, A., \& Salmiza, S. (2014). Faktor penyumbang kepada kemerosotan penyertaan pelajar dalam aliran [Contributing factors to the decline in student participation in the stream]. Sains Humanika, 2(4), 63-71.

Hamdallah, A., Ozovehe, A., \& Dyaji, L. (2014). Impact of creative teaching on science pupils' academic perfomance. IOSR Journal of Research $\mathcal{E}$ Method in Education (IOSRJRME), 4(6), 40-44. https:/ / doi.org/10.9790/7388-04614044

Hamsiah Saee. (2004). Tahap Kreativiti Guru Sains Dan Amalannya Dalam Pengajaran [The level of creativity of science teachers and their practice in teaching]. Jurnal Penyelidikan MPBL, 5, 14-23.

Hedegaard, M. (2020). Ascending from the abstract to the concrete in school teaching the double move between theoretical concepts and children's concepts. Psychological Science and Education. 25(5), 44-57. https://doi.org/10.17759/pse.2020250504 
Henriksen, D., \& Mishra, P. (2015). We teach who we are: Creativity in the lives and practices of accomplished teachers. Teachers College Record, 117(7), 1-46.

Horng, J.-S., Hong, J.-C., ChanLin, L.-J., Chang, S.-H., \& Chu, H.-C. (2005). Creative teachers and creative teaching strategies. International Journal of Consumer Studies, 29(4), 352-358. https://doi.org/10.1111/j.1470-6431.2005.00445.x

Hosseini, A. S., \& Watt, A. P. (2010). The effect of a teacher professional development in facilitating students' creativity. Educational Research and Reviews, 5(8), 432-438.

Humble, S., Dixon, P., \& Mpofu, E. (2018). Factor structure of the Torrance Tests of Creative Thinking Figural Form A in Kiswahili speaking children: Multidimensionality and influences on creative behavior. Thinking Skills and Creativity, 27, 33-44. https://doi.org/10.1016/j.tsc.2017.11.005

Januchowski-Hartley, S. R., Sopinka, N., Merkle, B. G., Lux, C., Zivian, A., Goff, P., \& Oester, S. (2018). Poetry as a creative practice to enhance engagement and learning in conservation science. BioScience, 68(11), 905-911. https://doi.org/10.1093/biosci/biy105

Johansson, E. (2001). The Nobel E-Museum - A Modern science education project on internet. International Journal of Modern Physics C, 12(4), 527-532. https://doi.org/10.1142/S0129183101002188

Kandemir, M. A., Tezci, E., Shelley, M., \& Demirli, C. (2019). Measurement of creative teaching in mathematics class. Creativity Research Journal, 31(3), 272-283. https://doi.org/10.1080/10400419.2019.1641677

Kant, J., Burckhard, S., \& Meyers, R. (2017). Engaging high school girls in Native American culturally responsive STEAM activities. Journal of STEM Education: Innovations and Research, 18(5), 15-25.

Karampelas, K. (2019). Cross curricular science in elementary schools in Greece - The curriculum factor. International Journal of Learning, Teaching and Educational Research, 18(7), 16-32. https://doi.org/10.26803/ijlter.18.7.2

Kelemen-Finan, J., Scheuch, M., \& Winter, S. (2018). Contributions from citizen science to science education: an examination of a biodiversity citizen science project with schools in central Europe. International Journal of Science Education, 40(17), 20782098. https://doi.org/10.1080/09500693.2018.1520405

Kerby, H. W., Cantor, J., Weiland, M., Babiarz, C., \& Kerby, A. W. (2010). Fusion Science Theater presents The Amazing Chemical Circus: A new model of outreach that uses theater to engage children in learning. Journal of Chemical Education, 87(10), 1024-1030. https://doi.org/10.1021/ed100143j

Khabibah, E. N., Masykuri, M., \& Maridi, M. (2017). The effectiveness of module based on discovery learning to increase generic science skills. Journal of Education and Learning (EduLearn), 11(2), 146-153. https://doi.org/10.11591/edulearn.v11i2.6076

Kim, K. H. (2006). Can we trust creativity tests? A review of the Torrance Tests of creative thinking (TTCT). Creativity Research Journal, 18(1), 3-14. https://doi.org/10.1207/s15326934crj1801

Lam, S. L., Yeung, A., Lam, P., \& McNaught, C. (2010). Creativity and science learning in a science enrichment programme in Hong Kong. International Journal of Learning, 17(2), 429-437. https:// doi.org/10.18848/1447-9494/cgp/v17i02/46887

Liao, C. (2016). From interdisciplinary to transdisciplinary: An arts-integrated approach to STEAM education. Art Education, 69(6), 44-49. https:// doi.org/10.1080/00043125.2016.1224873

Lillo, V. M. B., \& Úbeda, A. I. P. (2017). Creativity and adolescence. European Journal of Investigation in Health, Psychology and Education, 7(3), 177-188.

Lin, W-W., \& Liu, C-Y. (2016). On exploring factors for creative science teaching . Bulletin 
of Educational Psychology, 48(1), 1-14. https://doi.org/10.6251/BEP.20150422

Maulidah, N., Sunanih, Rahman, \& Supriatna, N. (2021). Creative play and learning in natural environment to develop creative-ecoliteracy in elementary school students. Journal of Physics: Conference Series, 1764(1), 012112. https://doi.org/10.1088/1742-6596/1764/1/012112

Miller, E. C., \& Krajcik, J. S. (2019). Promoting deep learning through project-based learning: a design problem. Disciplinary and Interdisciplinary Science Education Research, 1(1), 7. https:/ / doi.org/10.1186/s43031-019-0009-6

Mohammad Rusdi, B. A. M., \& Zawawi, I. (2017). Kreativiti Pengajaran Guru Bahasa Arab Di Malaysia. Jurnal Kepimpinan Pendidikan, 4(4), 27-38.

Nachiappan, S., Muthaiah, L., \& Suffian, S. (2017). Analisis sikap murid terhadap mata pelajaran Sains di Sekolah Jenis Kebangsaan (Tamil) [Analysis of students' attitudes towards science subjects in national type schools]. Jurnal Pendidikan Sains $\begin{array}{llll}\text { Dan Matematik } & \text { Malaysia, }\end{array}$ https://doi.org/10.37134/jpsmm.vol7.no2.7.2017

Othman, R. (2009) Perkaitan antara kreativiti dan kemahiran penyelesaian masalah topik elektrokimia bagi pelajar tingkatan empat. [The relationship between creativity and problem-solving skills for the topic of electrochemistry for Form 4 students] (Unpublished Master's thesis, Universiti Teknologi Malaysia).

Purba, E. P. (2017). Analysis of the difficulties of the mathematical creative thinking process in the application of problem based learning model. Advances in Social Science, Education and Humanities Research (AISTEEL), 104, 265-268. https://doi.org/10.12691/education-7-11-1

Reeves, L. E., Bolton, E., Bulpitt, M., Scott, A., Tomey, I., Gates, M., \& Baldock, R. A. (2021). Use of augmented reality (AR) to aid bioscience education and enrich student $\begin{array}{lllll}\text { experience. Research in Learning Technology, } 29 . & \end{array}$ https://doi.org/10.25304/rlt.v29.2572

Sagmeister, K. J., Schinagl, C. W., Kapelari, S., \& Vrabl, P. (2021). Students' experiences of working with a socio-scientific issues-based curriculum unit using role-playing to negotiate antibiotic resistance. Frontiers in Microbiology, 11. https://doi.org/10.3389/fmicb.2020.577501

Said, M. M. M., \& Alias, J. (2013). Kreativiti Pengajaran guru sekolah rendah di Malaysia [Teaching creativity of primary school teachers in Malaysia]. Jurnal Psikologi Malaysia, 27, 71-97.

Saorín, J. L., Melian-Díaz, D., Bonnet, A., Carbonell Carrera, C., Meier, C., \& De La TorreCantero, J. (2017). Makerspace teaching-learning environment to enhance creative competence in engineering students. Thinking Skills and Creativity, 23, 188-198. https://doi.org/10.1016/j.tsc.2017.01.004

Schvartzer, M., Elazar, M., \& Kapon, S. (2021). Guiding physics teachers by following in Galileo's footsteps. Science \& Education, 30(1), 165-179. https://doi.org/10.1007/s11191-020-00160-4

Shazana, S. (2016). Kajian Perbandingan Tahap Dan Amalan Kreativiti Guru -Guru Sains Sekolah Berprestasi Tinggi (SBT), Sekolah Kluster Kecemerlangan (SKK)Dengan Sekolah Rendah Biasa (SK) Di Putrajaya [A comparative study of the level and practice of creativity of science teachers of high performance schools (SBT), cluster of excellence schools (SKK) with ordinary primary schools (SK) in Putrajaya] (Unpublished Master thesis, Universiti Pendidikan Sultan Idris).

Toth, D., \& Kayler, M. (2015). Integrating role-playing games into computer science courses as a pedagogical tool. Proceedings of the 46th ACM Technical Symposium on Computer Science Education, 386-391. https:// doi.org/10.1145/2676723.2677236

Wagh, A., Cook-Whitt, K., \& Wilensky, U. (2017). Bridging inquiry-based science and 
constructionism: Exploring the alignment between students tinkering with code of computational models and goals of inquiry. Journal of Research in Science Teaching, 54(5), 615-641. https://doi.org/10.1002/tea.21379

Wartono, W., Hudha, M. N., \& Batlolona, J. R. (2017). How are the physics critical thinking skills of the students taught by using inquiry-discovery through empirical and theorethical overview? EURASIA Journal of Mathematics, Science and Technology Education, 14(2). https://doi.org/10.12973/ejmste/80632

\section{Appendix 1}

\section{PART B: CREATIVE TEACHING PRACTICES OF SCIENCE TEACHERS}

Instructions:

Please tick (/) the appropriate box to represent your level of agreement for each item based on the scale below:

1: (STS) Strongly disagree

2: (TS) Disagree

3: (N) Neutral

4: (S) Agree

5: (SS) Strongly agree

\begin{tabular}{|l|l|c|c|c|c|c|}
\hline No & \multicolumn{1}{|c|}{ Statement } & 1 & 2 & 3 & 4 & 5 \\
\multicolumn{1}{|c|}{ Teacher Knowledge } & TS & N & S & SS \\
\hline 1. & I know the content of the science subjects taught. & & & & & \\
\hline 2. & I know the science teaching method for science subjects. & & & & & \\
\hline 3. & $\begin{array}{l}\text { I know the content of the Science subjects taught the } \\
\text { level of students' ability. }\end{array}$ & & & & \\
\hline 4. & I know about the choosing teaching resources. & & & \\
\hline 5. & $\begin{array}{l}\text { I know to prescribe the in determining teaching } \\
\text { objectives. }\end{array}$ & & & & & \\
\hline 6. & $\begin{array}{l}\text { I use real actual materials from the environment for } \\
\text { teaching (Examples: leaves, stones, fruits, insects, } \\
\text { recycled materials, etc.) }\end{array}$ & & & & & \\
\hline 7. & $\begin{array}{l}\text { I conduct teaching activities outside of the classroom to } \\
\text { attract student's attention to the science subjects. }\end{array}$ & & & & & \\
\hline 8. & $\begin{array}{l}\text { Appropriate outdoor activities further facilitate my } \\
\text { students to relate science lessons to daily life. }\end{array}$ & & & & & \\
\hline 9. & $\begin{array}{l}\text { I encourage the appropriate use of the senses, and this } \\
\text { helps students in learning which helps students learn } \\
\text { Science better (smell, touch, hear, see, or taste). }\end{array}$ & & & & & \\
\hline 10. & $\begin{array}{l}\text { I modified the actual material as teaching aids for the } \\
\text { teaching of Science. }\end{array}$ & & & & & \\
\hline
\end{tabular}

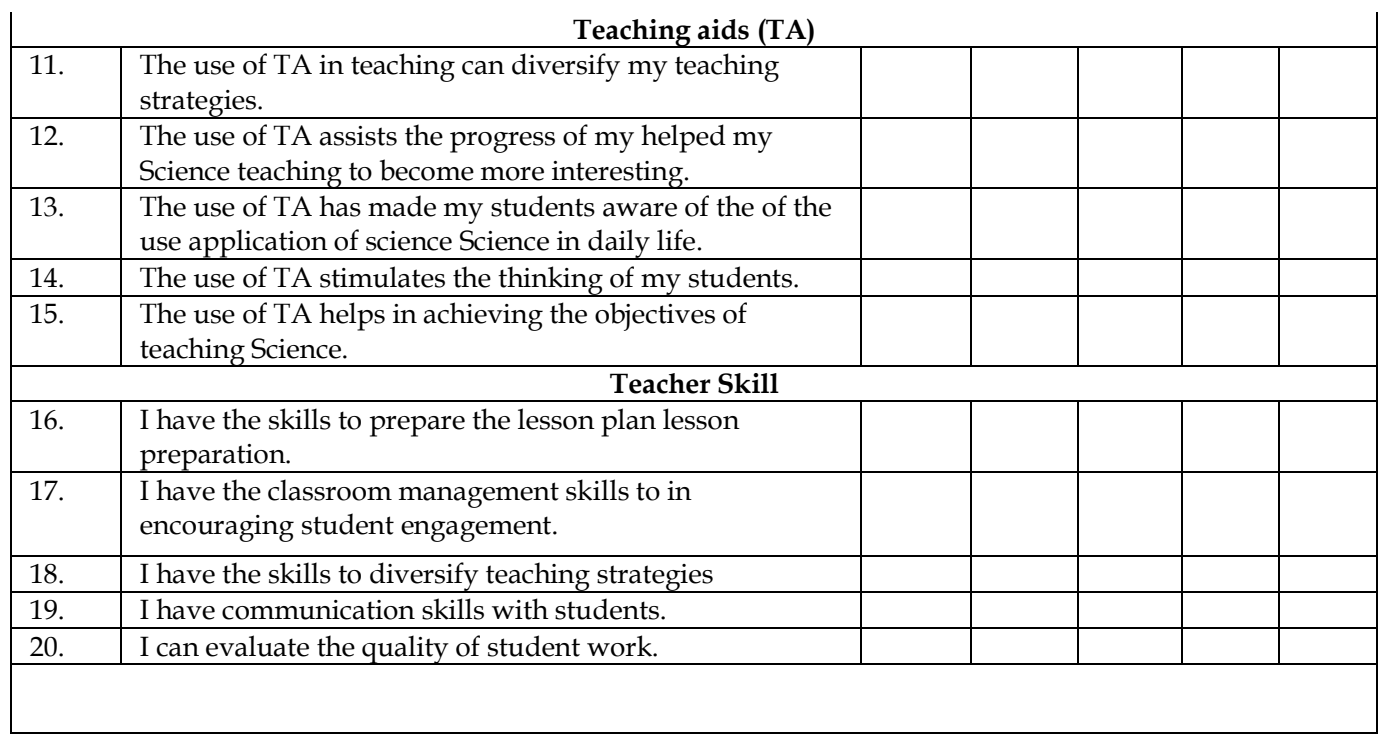




\begin{tabular}{|c|c|c|c|c|c|c|}
\hline No & Statement & $\begin{array}{c}1 \\
\text { STS }\end{array}$ & $\begin{array}{c}2 \\
\text { TS }\end{array}$ & $\begin{array}{l}3 \\
\mathbf{N}\end{array}$ & $\begin{array}{l}4 \\
\mathrm{~S}\end{array}$ & $\begin{array}{c}5 \\
\text { SS }\end{array}$ \\
\hline \multicolumn{7}{|c|}{ Science Process Skills } \\
\hline 21. & I know every element in Science process skills & & & & & \\
\hline 22. & $\begin{array}{l}\text { I diversify teaching methods to achieve students science } \\
\text { process skills. }\end{array}$ & & & & & \\
\hline 23. & $\begin{array}{l}\text { I conduct practical activities to achieve students science } \\
\text { process skills. }\end{array}$ & & & & & \\
\hline 24. & $\begin{array}{l}\text { I use additional tools to achieve students science process } \\
\text { skills. }\end{array}$ & & & & & \\
\hline 25. & I conduct active teaching in Science classes & & & & & \\
\hline \multicolumn{7}{|c|}{ Teacher Attitude } \\
\hline 26. & $\begin{array}{l}\text { I allow students to ask questions and come up with their } \\
\text { ideas }\end{array}$ & & & & & \\
\hline 27. & $\begin{array}{l}\text { I encourage group learning for the brainstorming of } \\
\text { ideas. }\end{array}$ & & & & & \\
\hline 28. & $\begin{array}{l}\text { I apply elements of high-level thinking skills in the } \\
\text { teaching of Science }\end{array}$ & & & & & \\
\hline 29. & $\begin{array}{l}\text { I apply elements of high-level thinking skills in the } \\
\text { teaching of Science. }\end{array}$ & & & & & \\
\hline 30. & I always encourage students to learn and enjoy Science & & & & & \\
\hline
\end{tabular}

\section{Appendix 2}

\section{ACTIVITY 1: PICTURE CONSTRUCTION (10 MINUTES)}

On this page, there is a curved shape. Think of a picture or an object that you can draw using this curved shape as part of the picture or object. Try to think of a picture image that no one else has ever thought. of. Add new thoughts to the first thought so that a picture can be produced that can tell an interesting and exciting story. Once the picture image is ready, think of a name or title for it. Write the title in the space provided at the bottom of the page. Make the title as unusual as possible so that it can explain your story.

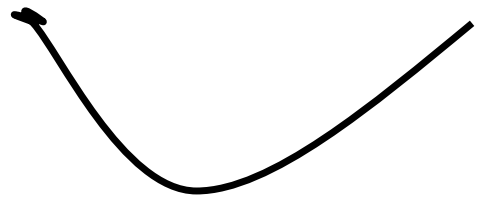

TITLE:

\section{ACTIVITY 2: PICTURE COMPLETION (10 Minutes)}

By adding lines to the diagrams on this page as well and the following pages, you will be able to draw some interesting exciting objects or pictures. Again, try to think of pictures images of things that no one else has ever thought of. Now, try to think again and give additional ideas to the first thought so that it canto establish an interesting exciting story as complete as possible. Think of an interesting title as well for each painting you have drawn. Write the title in the space provided at the bottom of each drawing.
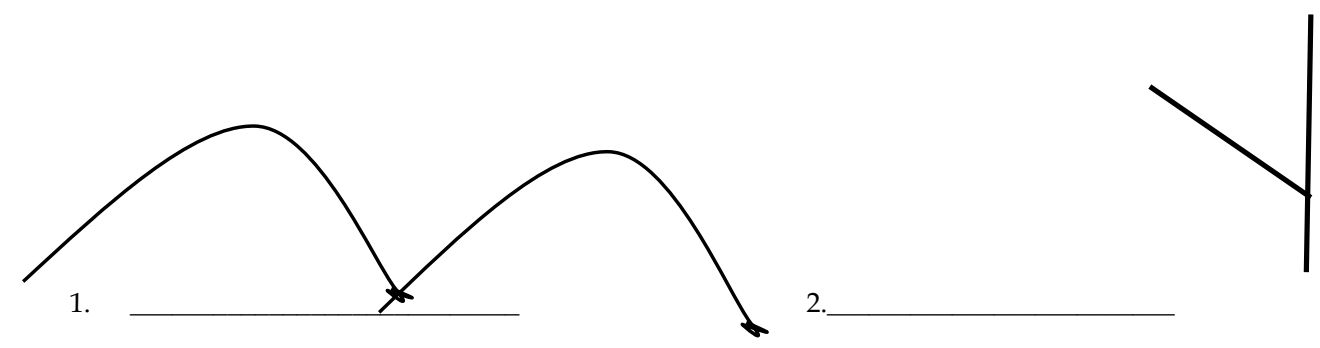

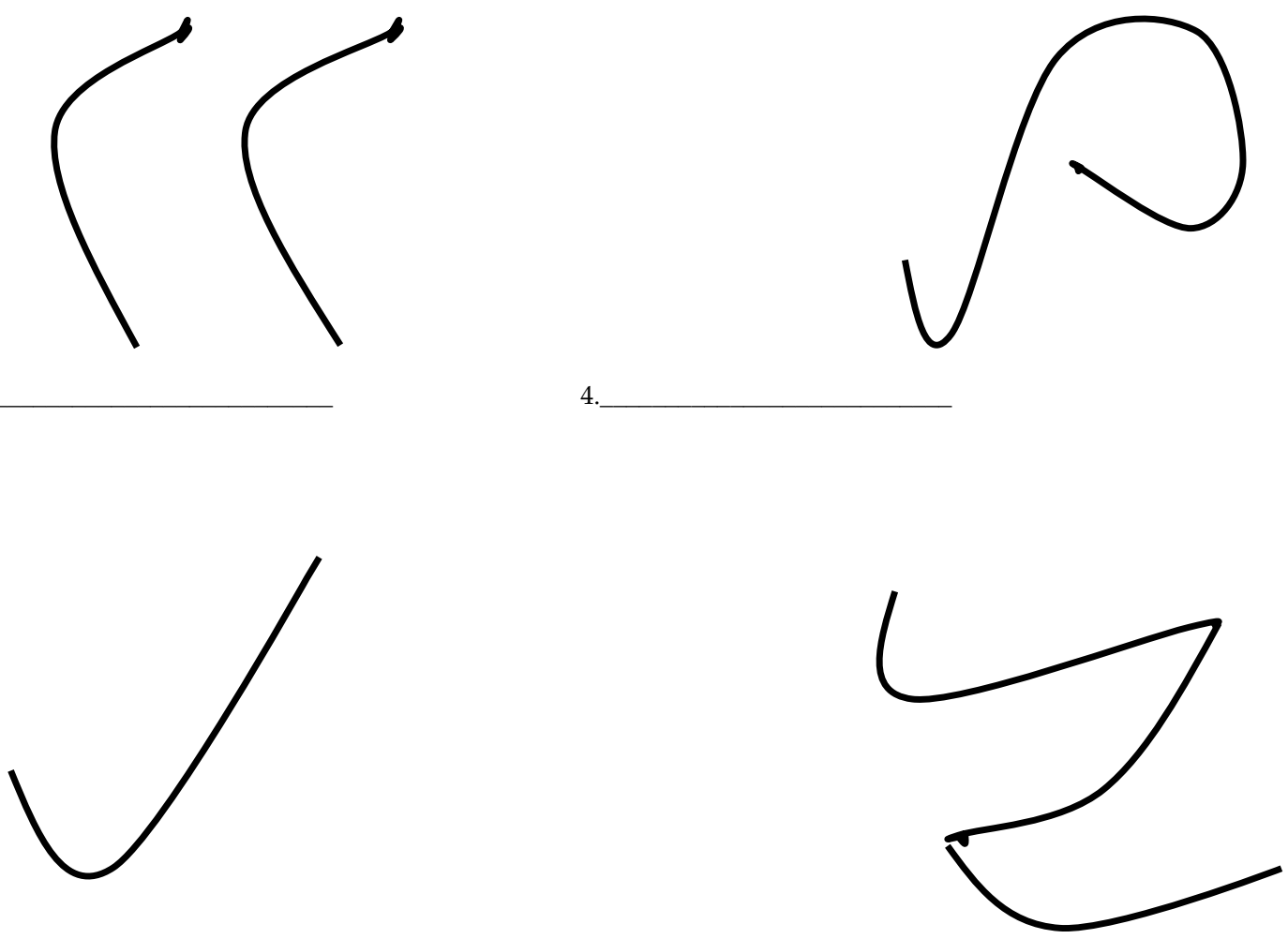

5.
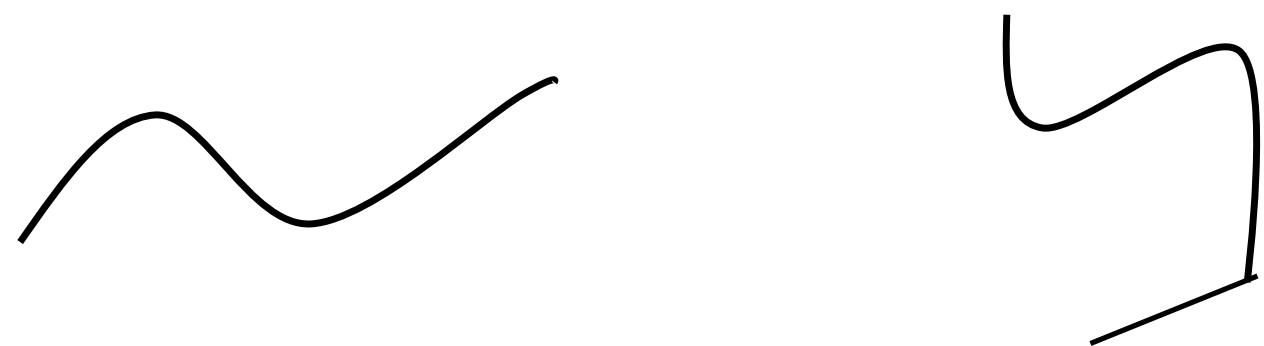

P

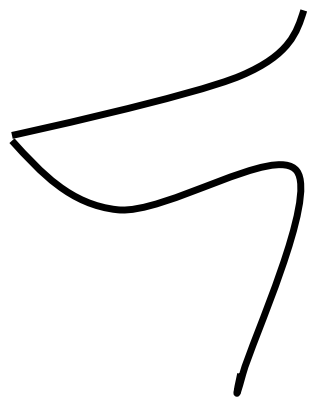

9.

10.

http://ijlter.org/index.php/ijlter 


\section{ACTIVITY 3: LINES (10 minutes)}

Based on the pair of straight lines on this page and also on the next page, how many objects or pictures can you draw in ten minutes?

The pair of straight lines should be an integral part of whatever object or picture you draw. Prepare the drawing with a pencil or color. You can draw anywhere - anywhere you like. For example, you can draw between that pair of straight lines, inside that pair of straight lines, and even outside that pair of straight consecutive lines. Try to think of things or pictures that no one else has ever thought of. Make as many different types of objects or pictures images as possible. Add new thoughts if you can. The drawing should be drawn in such a way to that it can explain as fully as possible the reason for the interesting exciting story. Write the name or title of each drawing in the space provided.

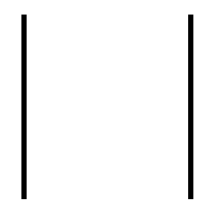

$\mid$ 